\title{
Effects of increasing the intake of dietary $\beta$-glucans by exchanging wheat for barley on nutrient digestibility, nitrogen excretion, intestinal microflora, volatile fatty acid concentration and manure ammonia emissions in finishing pigs
}

\author{
M. B. Lynch, T. Sweeney, J. J. Callan and J. V. O'Doherty ${ }^{\dagger}$ \\ School of Agriculture, Food Science and Veterinary Medicine, Lyons Research Farm, University College Dublin, Ireland
}

(Received 28 July 2006; Accepted 3 April 2007)

\begin{abstract}
An experiment (complete randomised design) was conducted to investigate the linear and quadratic effects of barley $\beta$-glucan inclusion level on total tract nutrient apparent digestibility, nitrogen excretion, intestinal microflora, volatile fatty acid (VFA) profile and manure ammonia emissions in pigs. Twenty-four boars $(66 \mathrm{~kg})$ were assigned to one of four treatments: (T1) $0 \mathrm{~g} / \mathrm{kg}$ barley (control diet) $(5.6 \mathrm{~g} / \mathrm{kg} \beta$-glucan), (T2) $222 \mathrm{~g} / \mathrm{kg}$ barley (12.1 g/kg $\beta$-glucan), (T3) $444 \mathrm{~g} / \mathrm{kg}$ barley (18.9 g/kg $\beta$-glucan) and (T4) $666 \mathrm{~g} / \mathrm{kg}$ barley (25 $\mathrm{g} / \mathrm{kg} \beta$-glucan). Barley was substituted for wheat in the diet. The diets were formulated to contain similar concentrations of digestible energy and digestible lysine. There was a linear decrease $(\mathrm{P}<0.001)$ in the total tract apparent digestibility of dry matter, organic matter, gross energy and neutral-detergent fibre with increasing $\beta$-glucan concentration. Faecal nitrogen excretion was affected by dietary $\beta$-glucan concentration (quadratic $\mathrm{P}<0.05$ ). There was a linear decrease in Enterobacteria concentrations $(\mathbb{P}<0.05)$ with increasing dietary $\beta$-glucan concentration. Increasing dietary barley levels caused a linear decrease in colonic $(\mathrm{P}<0.01)$ and caecal $\mathrm{pH}(\mathrm{P}<0.001)$. Total caecal VFA and propionic acid were affected by dietary $\beta$-glucan concentration (quadratic, $\mathrm{P}<0.05$ ). There was a linear decrease in the proportion of acetic acid $(\mathrm{P}<0.001)$, isobutyric acid $(\mathrm{P}<0.01)$ and isovaleric acid $(\mathrm{P}<0.05)$ with increasing levels of dietary barley in both the caecum and colon. There was a linear increase in the proportion of propionic acid $(\mathrm{P}<0.001)$ and butyric acid $(\mathrm{P}<0.05)$ with increasing barley in the colon. In conclusion, high level of dietary $\beta$-glucan $(25 \mathrm{~g} / \mathrm{kg})$ is required to reduce offensive odour forming branched-chain VFAs; however, diet digestibility is compromised at such levels.
\end{abstract}

Keywords: ammonia, barley, pigs, volatile fatty acids

\section{Introduction}

Mixed linked $\beta(1 \rightarrow 3,1 \rightarrow 4)$-D-glucan ( $\beta$-glucans) are cell wall nonstarch polysaccharides (NSPs) of barley endosperm and are classified as dietary fibre. Barley $\beta$-glucans resist hydrolysis by mammalian alimentary enzymes but can be hydrolysed and fermented by gastro-intestinal microflora through the secretion of hydrolases (Roberfroid, 1993) in the front and hindgut (Bach Knudsen and Hansen, 1991). $\beta$-glucans are readily fermented by bifidobacteria and lactobacilli species, promoting cell proliferation and production of short-chain fatty acids (SCFAs) (Charalampopoulos et al., 2002; 0'Connell et al., 2005). A rise in SCFA concentration through fermentation lowers

${ }^{\dagger}$ E-mail: john.vodoherty@ucd.ie digesta $\mathrm{pH}$, thus creating an unsustainable environment for $\mathrm{pH}$-sensitive pathogenic bacteria. A low carbohydrate-toprotein ratio in the large intestine leads to an increase in proteolytic fermentation (Aumaitre et al., 1995). Ammonia and odorous branched-chain fatty acids (BCFAs) are produced from the fermentation of amino acids (Macfarlane and Macfarlane, 2003). Isobutyric and isovaleric are metabolic end products from the fermentation of valine and leucine (Mackie, 1995). However, if the level of NSPs available for microbial fermentation are increased, BCFAs, odour and ammonia levels are reduced $\left(0^{\prime}\right.$ Connell et al., 2005; Garry et al., 2007). By increasing the carbohydrate to protein ratio entering the large intestine, nitrogen $(\mathrm{N})$ excretion shifts from the more volatile urinary $\mathrm{N}$ to faecal $\mathrm{N}$ (Mroz et al., 2000; 0'Connell et al., 2006), which is more stable. 
Effect of barley levels on nutrient digestibility and intestinal microflora

However, barley $\beta$-glucans also exhibit anti-nutritive properties. The physical enclosure of dietary nutrients by cell wall NSPs prevents the diffusion of nutrients and digestive enzymes (De Lange, 2000) resulting in a reduction in digestibility (Johnson and Gee, 1981) and average daily gain of pigs offered barley-based diets compared with wheat-based diets (Nielsen et al., 2000). O'Connell et al. (2005) showed that total tract apparent digestibility is improved with exogenous $\beta$-glucanase supplementation; however, the beneficial properties of $\beta$-glucans in barley are removed. Therefore, the objective of this study was to investigate the effects of increasing the intake of dietary $\beta$-glucans by exchanging wheat for barley on diet digestibility, $N$ retention, $N$ excretion, intestinal microflora, volatile fatty acid (VFA) concentration and manure ammonia emissions in finishing pigs.

\section{Material and methods}

All procedures described in this experiment were conducted under experimental licence from the Irish Department of Health in accordance with the Cruelty to Animals Act (1876) and the European Communities (Amendments of the Cruelty to Animals Act, 1976) Regulations (1994).

\section{Experimental design and diets}

The experiment was designed as a complete randomised design comprising four dietary treatments. All diets were formulated to have identical concentrations of digestible energy (DE) (13.7 MJ/kg) and ileal digestible lysine $(8.5 \mathrm{~g} / \mathrm{kg})$ (Sauvant et al., 2004). Barley replaced wheat and soya oil was adjusted to maintain $\mathrm{DE}$. The ileal digestible amino acid requirements were met relative to lysine (Close, 1994). High protein diets $(200 \mathrm{~g} / \mathrm{kg})$ were used in the current study so that the effects of $\beta$-glucan on protein degradation could be examined. The experimental treatments were as follows: (T1) $0 \mathrm{~g} / \mathrm{kg}$ barley (control diet) $(5.6 \mathrm{~g} / \mathrm{kg} \beta$-glucan), (T2) $222 \mathrm{~g} / \mathrm{kg}$ barley (12.1 g/kg $\beta$-glucan), (T3) $444 \mathrm{~g} / \mathrm{kg}$ barley $(18.9 \mathrm{~g} / \mathrm{kg} \beta$-glucan) and (T4) $666 \mathrm{~g} / \mathrm{kg}$ barley $(25 \mathrm{~g} / \mathrm{kg}$ $\beta$-glucan). All diets were fed in meal form. The dietary composition and analysis are presented in Table 1.

\section{Animals and management}

Twenty-four finishing boars (progeny of Meat line boars $\times$ (Large White $\times$ Landrace sow)) with an initial live weight of 66 (s.d. $=3.4) \mathrm{kg}$ were used in this experiment. The pigs were blocked on the basis of live weight and were randomly allocated to one of four dietary treatments. The pigs were allowed a 14-day dietary adaptation period after which time they were weighed and 16 pigs were selected according to a uniform weight and transferred to individual metabolism crates. The pigs were given a further 5 days to adapt to the metabolism crates before collections began. The collection period was subdivided into two parts to facilitate studies on ammonia emission (days 1 to 2) and apparent digestibility and $\mathrm{N}$ balance (days 3 to 7). The daily
Table 1 Composition and analysis of experimental diets

\begin{tabular}{|c|c|c|c|c|}
\hline & \multicolumn{4}{|c|}{ Treatment } \\
\hline & 1 & 2 & 3 & 4 \\
\hline \multicolumn{5}{|l|}{ Ingredients (g/kg) } \\
\hline Barley & 0 & 222.0 & 444.0 & 666.0 \\
\hline Wheat & 704.0 & 470.0 & 234.0 & 0 \\
\hline Soya-bean meal & 265.0 & 267.0 & 271.0 & 273.0 \\
\hline Soya oil & 6.0 & 16.0 & 26.0 & 36.0 \\
\hline Dicalcium phosphate & 7.5 & 7.5 & 7.5 & 7.5 \\
\hline Limestone & 15.0 & 15.0 & 15.0 & 15.0 \\
\hline Mineral and vitamin $\mathrm{mix}^{\dagger}$ & 2.5 & 2.5 & 2.5 & 2.5 \\
\hline \multicolumn{5}{|l|}{ Analysed composition $(\mathrm{g} / \mathrm{kg})$} \\
\hline Dry matter & 870.0 & 883.0 & 886.0 & 892.0 \\
\hline Crude protein $(\mathrm{N} \times 6.25)$ & 194.6 & 190.6 & 205.1 & 197.0 \\
\hline Neutral-detergent fibre & 103.1 & 116.3 & 128.8 & 142.2 \\
\hline Acid-detergent fibre & 37.4 & 43.7 & 49.9 & 50.5 \\
\hline Crude ash & 40.6 & 51.1 & 49.9 & 50.5 \\
\hline Gross energy (MJ/kg) & 15.9 & 16.2 & 16.5 & 16.9 \\
\hline Total $\beta$-D-glucan & 5.6 & 12.1 & 18.9 & 25.4 \\
\hline Insoluble $\beta$-glucan & 1.02 & 4.34 & 7.81 & 10.73 \\
\hline Soluble $\beta$-glucan & 4.58 & 7.76 & 11.09 & 14.67 \\
\hline Total $\beta$-glucan: crude protein & 0.029 & 0.063 & 30.092 & 20.129 \\
\hline \multicolumn{5}{|l|}{ Calculated composition ( $\mathrm{g} / \mathrm{kg})$} \\
\hline Digestible energy ${ }^{\ddagger}$ & 13.75 & 13.75 & 13.70 & 13.70 \\
\hline Digestible lysine $^{\ddagger}$ & 8.5 & 8.2 & 8.3 & 8.3 \\
\hline $\begin{array}{l}\text { Digestible methionine and } \\
\text { cysteine }^{\ddagger}\end{array}$ & 5.5 & 5.4 & 5.3 & 5.2 \\
\hline Digestible threonine $e^{\ddagger}$ & 5.5 & 5.5 & 5.5 & 5.5 \\
\hline Digestible tryptophan ${ }^{\ddagger}$ & 2.0 & 2.0 & 2.0 & 2.0 \\
\hline
\end{tabular}

${ }^{\dagger}$ Provided per $\mathrm{kg}$ of complete diet: $3 \mathrm{mg}$ retinol, $0.05 \mathrm{mg}$ cholecalciferol, $40 \mathrm{mg}$ alpha-tocopherol, $90 \mathrm{mg}$ copper as copper II sulphate, $100 \mathrm{mg}$ iron as iron II sulphate, $100 \mathrm{mg}$ zinc as zinc oxide, $0.3 \mathrm{mg}$ selenium as sodium selenite, $25 \mathrm{mg}$ manganese as manganous oxide and $0.2 \mathrm{mg}$ iodine as calcium iodate on a calcium sulphate/calcium carbonate carrier.

FSauvant et al. (2004).

feed ad libitum allowance (DE intake (MJ/day) $=3.44 \times$ (live weight) $^{0.54}$ (Close, 1994) was divided over two meals and was based on an anticipated DE concentration of $13.7 \mathrm{MJ} / \mathrm{kg}$. The mean feed intake was $2.00( \pm 0.05) \mathrm{kg}$. Water was provided with meals in a 1:1 ratio. Between meals, fresh water was provided ad libitum. The metabolism crates were located in a temperature-controlled room, maintained at $22^{\circ} \mathrm{C}\left( \pm 1.5^{\circ} \mathrm{C}\right)$.

\section{Ammonia emissions}

Four separate collections of total faeces and urine were taken at 12-h intervals during collection days 1 to 2 . Following collection, the excreta were stored separately in sealed containers at $4^{\circ} \mathrm{C}$. After the last collection, the urine and faeces samples were mixed together ( $\mathrm{w} / \mathrm{w}$ ) according to the original excretion ratio. Samples $(2 \mathrm{~kg})$ of the manure homogenate from each pig were placed in duplicate, in sealed containers within a climate-controlled room maintained at $20^{\circ} \mathrm{C}$. Ammonia emission from the manure was 
measured over $240 \mathrm{~h}$ from the first container, in a laboratory scale set-up according to the method of Derikx and Aarnink (1993). The equipment consisted of a vessel containing $2 \mathrm{~kg}$ slurry, vacuum pump and three impingers in series per sample. The first two impingers contained $1 \mathrm{~mol} / \mathrm{l}$ nitric acid and the third impinger contained water. The ventilation rate in the container was $4.2 \mathrm{l} / \mathrm{min}$. The first impinger was replaced at 48,96 and $144 \mathrm{~h}$ and the second impinger was replaced at $96 \mathrm{~h}$. Samples were taken from all three impingers at $240 \mathrm{~h}$. The concentration of ammonia-nitrogen $\left(\mathrm{NH}_{3}-\mathrm{N}\right)$ in the impingers was determined by the microdiffusion technique of Conway (1957). Ammonia production (mg) from manure is compared between the different dietary treatments using the quantity volatilised from 0 to $240 \mathrm{~h} / \mathrm{g}$ of $\mathrm{N}$ intake. The sample in the second ventilated container was used to conduct $\mathrm{pH}$ analysis of the slurry whenever the first impinger was replaced.

Total tract apparent digestibility and nitrogen balance study During collections, urine was collected in a plastic container, via a funnel below the crate, containing $20 \mathrm{ml}$ of sulphuric acid $\left(25 \% \mathrm{H}_{2} \mathrm{SO}_{4}\right)$. To avoid $\mathrm{N}$ volatilisation, the funnel was sprayed four times daily with a weak solution of sulphuric acid $\left(2 \% \mathrm{H}_{2} \mathrm{SO}_{4}\right)$. The urine volume was recorded daily and a 50-ml sample was collected and frozen for laboratory analysis. Total faeces weight was recorded daily and oven dried at $100^{\circ} \mathrm{C}$. A sample of freshly voided faeces was collected daily and then frozen for $\mathrm{N}$ analysis. At the end of the collection period, the faeces samples were pooled and a subsample retained for laboratory analysis. Feed samples were collected each day and retained for chemical analysis.

\section{Microbiology}

All 24 pigs remained on their respective dietary treatments until slaughter. Digesta samples (approximately $10( \pm 1) \mathrm{g}$ ) were aseptically removed in aerobic conditions from the caecum and distal colon of each animal immediately after slaughter and stored in sterile containers (Sarstedt, Wexford, Ireland) on ice and transported to the laboratory within $7 \mathrm{~h}$. Lactobacillus spp. and Enterobacteria were isolated and counted according to the method described by O'Connell et al. (2005). Lactobaccilus spp. were chosen because of their health-promoting properties (Gibson and Roberfroid, 1995) while Enterobacteria were chosen because harmful effects of some species in the gastrointestinal tract (Gibson and Roberfroid, 1995).

\section{$\mathrm{pH}$ measurements}

Samples of digesta from the caecum and distal colon were taken and placed in universal containers. The $\mathrm{pH}$ of the digesta was taken on site, immediately after collection. All $\mathrm{pH}$ measurements were made on a Mettler Toledo MP 220 $\mathrm{pH}$ meter, which was calibrated with certified $\mathrm{pH} 4$ and 7 buffer solutions. Distilled water was added to some very viscous samples to enable their $\mathrm{pH}$ to be read.
Volatile fatty acid sampling and analysis

Samples of digesta from the caecum and the colon of individual pigs $(n=24)$ were taken for VFA analysis. VFA concentrations in the digesta were determined using a modified method of Porter and Murray (2001). One gram of sample was diluted with distilled water $(2.5 \times$ weight of sample) and centrifuged at $1400 \times \mathbf{g}$ for $4 \mathrm{~min}$ (Sorvall $\mathrm{GLC}-2 \mathrm{~B}$ laboratory centrifuge). One $\mathrm{ml}$ of the subsequent supernatant and $1 \mathrm{ml}$ of the internal standard $(0.5 \mathrm{~g}$ 3 -methyl- $n$-valeric acid in 1 I of $0.15 \mathrm{~mol} / / \mathrm{l}$ oxalic acid) were mixed with $3 \mathrm{ml}$ of distilled water. Following centrifugation to remove the precipitate, the sample was filtered through Whatman $0.45 \mu \mathrm{m}$ polyethersulphone membrane filters into a chromatographic sample vial. One $\mu$ l of the sample was injected into a model 3800 Varian gas chromatograph with a $25 \mathrm{~m} \times 0.53 \mathrm{~mm}$ i.d. megabore column (coating CP-Wax 58 (FFAP) - CB (no. CP7614)) (Varian, Middelburg, The Netherlands).

\section{Laboratory analysis of samples}

Proximate analysis of diets for dry matter (DM) and ash were carried out according to Association of Official Analytical Chemists (1995). The DM of the feed and faeces was determined after drying for $24 \mathrm{~h}$ at $103^{\circ} \mathrm{C}$. Ash was determined after ignition of a known weight of concentrates or faeces in a muffle furnace (Nabertherm, Bremen, Germany) at $500^{\circ} \mathrm{C}$ for $4 \mathrm{~h}$. The gross energy (GE) of feed and faeces samples was measured using an adiabatic bomb calorimeter (Parr Instruments, IL, USA). The neutral-detergent fibre (NDF) and acid-detergent fibre (ADF) content of feed and faeces was determined using a Fibertec extraction unit (Tecator, Sweden) according to the method of Van Soest et al. (1991). The soluble and insoluble $\beta$-glucan content was determined according to McCleary and Glennie-Holmes (1985). The crude protein content of the feed was determined as $\mathrm{N} \times 6.25$ using the LECO FP 528 instrument (Leco Instruments, UK Ltd, Newby Road, Hazel Grove, Stockport, SK7 5DA, Cheshire). The nitrogen content of faeces was analysed by the macro-Kjeldahl technique using a Buchii apparatus.

\section{Statistical analysis}

Linear and quadratic effects of dietary $\beta$-glucan concentration were tested using the general linear model procedure of Statistical Analysis System Institute (SAS, 1985). Metabolic live weight (live weight ${ }^{0.75}$ ) and daily feed intake were included as covariates in the model. The model is

$$
Y_{i}=\mu+\beta_{1} X_{i}+\beta_{2} X_{i}^{2}+e_{i}
$$

where $Y_{i}$ is the dependent variable, $\mu$ is the overall mean, $\beta_{1} X_{i}$ is the linear effect of $\beta$-glucan inclusion, $\beta_{2} X_{i}^{2}$ is the quadratic effect of $\beta$-glucan inclusion and $e_{i}$ is the residual error. The manure $\mathrm{pH}$ data measured over 10 days was performed by repeated measures analysis using the Proc Mixed procedure of SAS 6.14 (Littell et al., 1996). The 
individual pig served as the experimental unit. The probability level that denotes significance is $P<0.05$. The data in the tables are presented as least-square means \pm standard error of the mean, which was calculated as a pooled value across treatments.

\section{Results}

Coefficient of total tract apparent digestibility and nitrogen balance study

The effect of dietary treatment on the coefficient of total tract apparent digestibility of nutrients and $\mathrm{N}$ balance are presented in Table 2. Dietary treatment had no significant effect on food or $\mathrm{N}$ intake. There was a linear decrease in the digestibility of $\mathrm{DM}\left(\beta_{1}=-0.00005\right.$; s.e. 0.00001 ; $P<0.001)$, organic matter (OM) $\left(\beta_{1}=-0.00006\right.$; s.e. 0.000009; $P<0.001)$, GE $\left(\beta_{1}=-0.00005\right.$; s.e. 0.00001 ; $P<0.001)$, NDF $\left(\beta_{1}=-0.0002 ;\right.$ s.e. $\left.0.00004 ; P<0.001\right)$, ADF $\left(\beta_{1}=-0.0005 ;\right.$ s.e. $\left.0.00005 ; P<0.001\right)$ and $\mathrm{N}$ $\left(\beta_{1}=-0.00004\right.$; s.e. $\left.0.00002 ; P<0.05\right)$ as the level of barley in the diet increased.

Increasing levels of dietary barley resulted in a linear increase in faecal DM content $\left(\beta_{1}=0.004\right.$; s.e. 0.002 ; $P<0.05)$ and faeces output $\left(\beta_{1}=0.0003\right.$; s.e. 0.0002 ; $P<0.05)$. Faecal $\mathrm{N}$ excretion was affected by dietary barley level (quadratic, $P<0.05$ ). Dietary treatments had no significant effect on $\mathrm{N}$ retention $(P>0.05)$.

\section{Microbiology study}

The effect of dietary treatment on selected microbial populations and $\mathrm{pH}$ in the caecum and colon are presented in Table 3. There was a linear decrease in Enterobacteria concentrations $\left(\beta_{1}=-0.001\right.$; s.e. $\left.0.0005 ; P<0.05\right)$ with increasing dietary barley level in the caecum. Colonic $\left(\beta_{1}=-0.0003\right.$; s.e. $\left.0.0001 ; P<0.01\right)$ and caecal digesta pH $\quad\left(\beta_{1}=-0.0003 ;\right.$ s.e. $\left.0.0001 ; \quad P<0.001\right)$ linearly decreased as the level of barley in the diet increased. Dietary treatments had no significant effect on Lactobacilli concentrations in the caecum or colon $(P>0.05)$.

\section{Volatile fatty acid study}

The effect of dietary treatment on the concentration and profile of caecal and colonic VFA is shown in Table 4. Total VFA concentrations and proportion of propionic acid were affected by dietary barley level (quadratic, $P<0.05$ ) in the caecum. There was a linear decrease in acetic acid $\left(\beta_{1}=-0.0001\right.$; s.e. $\left.0.00002 ; P<0.001\right)$, isobutyric acid $\left(\beta_{1}=-0.000003\right.$; s.e. $\left.0.000001 ; P<0.05\right)$, isovaleric acid $\left(\beta_{1}=-0.00001\right.$; s.e. $\left.0.000002 ; P<0.05\right)$, acetic acid: propionic acid ratio $\left(\beta_{1}=-0.001\right.$; s.e. $\left.0.0002 ; P<0.001\right)$ and a linear increase in propionic acid $\left(\beta_{1}=0.0001\right.$; s.e. $=0.00002 ; P<0.001)$ with increasing levels of dietary barley in the caecum.

There was a linear increase in the total concentration of VFA $\left(\beta_{1}=0.066\right.$; s.e. $\left.0.023 ; P<0.01\right)$ and in the molar

Table 2 Effect of dietary barley $\beta$-glucan level on total tract nutrient apparent digestibility and nitrogen utilisation (least-square means \pm s.e.)

\begin{tabular}{|c|c|c|c|c|c|c|c|}
\hline & \multicolumn{4}{|c|}{ Treatment } & \multirow[b]{2}{*}{ s.e. } & \multicolumn{2}{|c|}{ Significance $^{\dagger}$} \\
\hline & 1 & 2 & 3 & 4 & & Linear & Quadratic \\
\hline$n$ & 4 & 4 & 4 & 4 & & & \\
\hline Barley $(\mathrm{g} / \mathrm{kg})$ & 0 & 222.0 & 444.0 & 666.0 & & & \\
\hline Dry-matter intake (kg/day) & 2.02 & 2.05 & 2.07 & 2.04 & 0.052 & ns & ns \\
\hline \multicolumn{8}{|l|}{ Digestibility coefficients } \\
\hline Dry matter & 0.89 & 0.87 & 0.86 & 0.86 & 0.005 & $* * *$ & ns \\
\hline Organic matter & 0.91 & 0.89 & 0.88 & 0.87 & 0.004 & $* * *$ & ns \\
\hline Nitrogen & 0.89 & 0.86 & 0.88 & 0.86 & 0.007 & * & ns \\
\hline Neutral-detergent fibre & 0.65 & 0.61 & 0.59 & 0.50 & 0.016 & $* * *$ & ns \\
\hline Acid-detergent fibre & 0.55 & 0.47 & 0.46 & 0.36 & 0.021 & $* * *$ & ns \\
\hline Gross energy & 0.89 & 0.87 & 0.86 & 0.85 & 0.005 & $* * *$ & ns \\
\hline Faeces dry matter $(\mathrm{g} / \mathrm{kg})$ & 280.0 & 289.0 & 304.0 & 303.0 & 8.28 & * & ns \\
\hline Fresh faeces output (kg/day) & 0.78 & 0.99 & 0.98 & 1.01 & 0.072 & * & ns \\
\hline Nitrogen intake (g/day) & 63.1 & 63.1 & 66.2 & 64.4 & 1.518 & ns & ns \\
\hline Faecal nitrogen excretion (g/day) & 7.6 & 9.9 & 9.0 & 10.2 & 0.646 & * & * \\
\hline Urinary nitrogen excretion (g/day) & 22.2 & 25.6 & 24.3 & 23.4 & 2.907 & ns & ns \\
\hline Total nitrogen excretion (g/day) & 29.7 & 35.6 & 33.3 & 33.6 & 2.918 & ns & ns \\
\hline Nitrogen retention (g/day) & 33.4 & 27.5 & 32.9 & 30.9 & 2.81 & ns & ns \\
\hline Nitrogen retention/intake & 0.53 & 0.43 & 0.49 & 0.48 & 0.043 & ns & ns \\
\hline Urine:faeces nitrogen ratio & 3.01 & 2.61 & 2.91 & 2.46 & 0.453 & ns & ns \\
\hline
\end{tabular}

${ }^{+}$Linear $=$linear response to dietary barley, quadratic $=$quadratic response to barley. ${ }^{*} P<0.05,{ }^{* *} P<0.01,{ }^{* *} P<0.001$, ns $=$ non-significant $(P>0.05)$. 
Lynch, Sweeny, Callan and O'Doherty

Table 3 Effect of dietary barley $\beta$-glucan level on microbial ecology and $\mathrm{pH}$ in the caecum and colon (least-square means \pm s.e.)

\begin{tabular}{|c|c|c|c|c|c|c|}
\hline & \multicolumn{4}{|c|}{ Treatment } & \multirow[b]{2}{*}{ s.e. } & \multirow{2}{*}{$\begin{array}{c}\text { Significance }^{\dagger} \\
\text { Linear }\end{array}$} \\
\hline & 1 & 2 & 3 & 4 & & \\
\hline$n$ & 6 & 6 & 6 & 6 & & \\
\hline Barley $(\mathrm{g} / \mathrm{kg})$ & 0 & 222.0 & 444.0 & 666.0 & & \\
\hline \multicolumn{7}{|c|}{ Caecum bacterial populations ( $\log _{10}$ c.f.u./ml digesta) } \\
\hline Enterobacteria spp. & 6.12 & 6.27 & 6.08 & 5.49 & 0.285 & * \\
\hline Lactobacilli spp. & 8.27 & 8.37 & 8.69 & 8.43 & 0.277 & ns \\
\hline Lactobacilli: enterobacteria & 1.39 & 1.42 & 1.43 & 1.55 & 0.094 & ns \\
\hline \multicolumn{7}{|c|}{ Colon bacterial populations ( $\log _{10}$ c.f.u./ml digesta) } \\
\hline Enterobacteria spp. & 6.29 & 5.95 & 5.62 & 5.77 & 0.319 & ns \\
\hline Lactobacilli spp. & 8.41 & 8.47 & 8.74 & 8.74 & 0.327 & ns \\
\hline Lactobacilli: enterobacteria & 1.35 & 1.46 & 1.61 & 1.53 & 0.113 & ns \\
\hline \multicolumn{7}{|l|}{$\mathrm{pH}$} \\
\hline Caecal pH & 5.39 & 5.42 & 5.26 & 5.20 & 0.051 & $* * *$ \\
\hline Colonic pH & 5.68 & 5.48 & 5.46 & 5.42 & 0.078 & $* *$ \\
\hline
\end{tabular}

${ }^{+}$Linear: linear response to dietary barley. There was no quadratic response to dietary barley $(P>0.05) .{ }^{*} P<0.05$, ${ }^{* *} P<0.01$, ${ }^{* * *} P<0.001$, ns $=$ nonsignificant $(P>0.05)$.

Table 4 The effect of dietary barley $\beta$-glucan level on total volatile fatty acids (VFA) concentration in digesta and molar propotions of VFA in the caecum and colon (least-square means \pm s.e.)

\begin{tabular}{|c|c|c|c|c|c|c|c|}
\hline & \multicolumn{4}{|c|}{ Treatment } & \multirow[b]{2}{*}{ s.e. } & \multicolumn{2}{|c|}{ Significance $^{\dagger}$} \\
\hline & 1 & 2 & 3 & 4 & & Linear & Quadratic \\
\hline$n$ & 6 & 6 & 6 & 6 & & & \\
\hline Barley (g/kg) & 0 & 222.0 & 444.0 & 666.0 & & & \\
\hline \multicolumn{8}{|l|}{ Caecum } \\
\hline Total VFA (mmol/l digesta water) & 322.1 & 283.9 & 311.6 & 327.4 & 13.02 & ns & * \\
\hline Acetic acid & 58.8 & 59.0 & 54.6 & 52.7 & 0.9 & $* * *$ & ns \\
\hline Propionic acid & 24.8 & 24.1 & 27.5 & 30.8 & 0.9 & $* * *$ & * \\
\hline Isobutyric acid & 0.5 & 0.6 & 0.4 & 0.4 & 0.1 & * & ns \\
\hline Butyric acid & 13.4 & 13.5 & 15.1 & 14.1 & 0.7 & ns & ns \\
\hline Isovaleric acid & 0.9 & 1.2 & 0.7 & 0.7 & 0.1 & * & ns \\
\hline Valeric acid & 1.6 & 1.6 & 1.8 & 1.4 & 0.1 & ns & ns \\
\hline Acetic:propionic acid ratio & 2.38 & 2.47 & 2.00 & 1.73 & 0.104 & *** & ns \\
\hline \multicolumn{8}{|l|}{ Colon } \\
\hline Total VFA (mmol/l digesta water) & 323.7 & 333.2 & 373.9 & 358.2 & 10.81 & $* *$ & ns \\
\hline Acetic acid & 57.7 & 56.3 & 53.5 & 51.4 & 0.9 & *** & ns \\
\hline Propionic acid & 23.5 & 24.2 & 25.9 & 28.9 & 0.9 & $* * *$ & ns \\
\hline Isobutyric acid & 0.9 & 0.9 & 0.7 & 0.6 & 0.1 & ** & ns \\
\hline Butyric acid & 13.9 & 14.8 & 16.3 & 15.6 & 0.5 & * & ns \\
\hline Isovaleric acid & 1.9 & 1.6 & 1.3 & 1.4 & 0.1 & * & ns \\
\hline Valeric acid & 2.0 & 2.1 & 2.2 & 2.0 & 0.2 & ns & ns \\
\hline Acetic: propionic acid ratio & 2.47 & 2.36 & 2.08 & 1.80 & 0.111 & $* * *$ & ns \\
\hline
\end{tabular}

${ }^{+}$Linear $=$linear response to dietary barley, quadratic $=$quadratic response to barley. ${ }^{*} P<0.05,{ }^{* *} P<0.01,{ }^{* * *} P<0.001$, ns $=$ non-significant $(P>0.05)$.

proportions of butyric acid $\left(\beta_{1}=0.00003\right.$; s.e. 0.00001 ; $P<0.05)$ and propionic acid $\left(\beta_{1}=0.0001\right.$; s.e. 0.00002 ; $P<0.001)$ with an increasing barley inclusion level in the colon. There was a linear decrease in the proportion of acetic acid $\left(\beta_{1}=-0.0001\right.$; s.e. $\left.0.00002 ; P<0.001\right)$, isobutyric acid $\left(\beta_{1}=-0.00001\right.$; s.e. $\left.0.000001 ; P<0.01\right)$, isovaleric acid $\left(\beta_{1}=-0.00001\right.$; s.e. $\left.0.000003 ; P<0.05\right)$ and acetic acid: propionic acid ratio $\left(\beta_{1}=-0.001\right.$; s.e. $0.0002 ; P<0.001)$ with increasing dietary barley level in the colon. 
Effect of barley levels on nutrient digestibility and intestinal microflora

Table 5 The effect of dietary barley level on ammonia production and slurry $\mathrm{pH}$ (least-square means \pm s.e.)

\begin{tabular}{|c|c|c|c|c|c|c|}
\hline & \multicolumn{4}{|c|}{ Treatment } & \multirow[b]{2}{*}{ s.e. } & \multirow{2}{*}{$\begin{array}{c}\text { Significance } \\
\text { Linear }\end{array}$} \\
\hline & 1 & 2 & 3 & 4 & & \\
\hline$n$ & 4 & 4 & 4 & 4 & & \\
\hline Barley $(\mathrm{g} / \mathrm{kg})$ & 0 & 222.0 & 444.0 & 666.0 & & \\
\hline Manure volume (kg/day) & 3.96 & 2.68 & 4.48 & 3.47 & 0.587 & ns \\
\hline \multicolumn{7}{|l|}{ Ammonia (mg/g N intake) } \\
\hline $0-96 \mathrm{~h}$ & 41.54 & 34.97 & 39.44 & 39.28 & 3.562 & ns \\
\hline $96-240 \mathrm{~h}$ & 72.11 & 51.10 & 53.05 & 50.75 & 7.879 & ns \\
\hline $0-240 \mathrm{~h}$ & 113.65 & 86.07 & 92.49 & 90.03 & 10.52 & ns \\
\hline Slurry pH (0-240 h) & 8.99 & 8.98 & 8.72 & 8.80 & 0.116 & ns \\
\hline
\end{tabular}

${ }^{\dagger}$ Linear $=$ linear response to dietary barley. There was no quadratic response to dietary barley $(P>0.05)$.

\section{Ammonia emission study}

The effects of dietary treatment on manure ammonia emissions and slurry $\mathrm{pH}$ during storage are presented in Table 5. There was no significant linear or quadratic effect of dietary barley on ammonia or slurry $\mathrm{pH}(P>0.05)$.

\section{Discussion}

Cereals are one of the major sources of dietary fibre in monogastric nutrition; however, the composition of the fibre may vary depending on its source (De Lange, 2000). Both wheat and barley contain anti-nutritional factors such as arabinoxylans and $\beta$-glucans. Elevated levels of these polysaccharides, in particular the soluble fraction, can cause an increase in digesta viscosity, preventing interaction between nutrients and digestive enzymes (Campbell and Bedford, 1992) and reducing nutrient digestibility (O'Connell et al., 2005) in pigs. However, decreases in ammonia emission and odour have been reported when sources of fermentable fibre are added to the diet (Garry et al., 2007) and $\beta$-glucans have been shown to have prebiotic properties (0'Connell et al., 2005). The objective of this study was to investigate the effects of increased levels of dietary $\beta$-glucans on diet digestibility, $N$ metabolism, intestinal microflora, VFA concentration and manure ammonia emissions in finishing pigs.

Bach Knudsen and Hansen (1991) reported substantial bacterial fermentation of $\beta$-glucans in the small intestine of the pig. This was attributed to the high solubility and easy degradation of $\beta$-glucans. However, previous work from our laboratory has shown that the beneficial effects of barley $\beta$-glucans such as a reduction in odour and ammonia emissions were removed as a result of $\beta$-glucanase and xylanase addition, while enzyme inclusion had no effect on wheat-based diets (O'Connell et al., 2005; Garry et al., 2007). This would indicate that not all of the $\beta$-glucans are broken down in the small intestine. If all the $\beta$-glucans were broken down in the small intestine, there would have been no response to the enzyme inclusion. Similarily,
Högberg and Lindberg (2004) found that digestion of $\beta$-glucans was more pronounced in the total tract than at the ileum indicating that some fermentation of $\beta$-glucans occurred in the large intestine. It is probably the soluble $\beta$-glucans that are broken down in the small intestine while the insoluble $\beta$-glucans pass into the large intestine, where they are fermented by bacteria. Barley $\beta$-glucans have been shown to be $70 \%$ soluble and $30 \%$ insoluble (Högberg, 2003). Secondly, this also would indicate that the response benefits obtained in the current study were due to an increasing barley content and not due to a decreasing wheat content in the diet.

There was a linear decrease in the apparent digestibility of DM, OM, NDF, ADF and GE with increasing levels of dietary barley. The linear decrease in digestibility coefficients corresponds to the elevated NSP concentrations. Analysis of the total $\beta$-glucan content of the diets was 5.6, $12.1,18.9$ and $25.4 \mathrm{~g} / \mathrm{kg}$ and the insoluble $\beta$-glucan content was $1.0,4.3,7.8$ and $10.7 \mathrm{~g} / \mathrm{kg}$ for the control, low, medium and high barley diets, respectively. NSPs from cell walls can physically hinder the access of digestive enzymes to nutrients that are enclosed inside the cell wall. As a consequence, degradation and utilisation of nutrients is limited, resulting in a depression of digestibility (De Lange, 2000). The decrease in diet digestibility recorded in the current experiment would indicate that pig performance could be compromised. However, dietary treatment had no effect on $\mathrm{N}$ retention in the current study. Previous work at this laboratory indicates no significant reduction in performance of grower-finisher pigs offered barley $v$. wheat-based diets (Garry et al., 2007). The lack of response maybe due to the fact that the diets were formulated to have similar DE concentrations and were offered to grower finisher pigs.

Although there is clear evidence in this study to demonstrate the anti-nutritive properties of barley $\beta$-glucan, its addition to the diet also resulted in reductions of BCFAs in the caecum and colon and digesta Enterobacteria in the caecum. As the $\beta$-glucan: protein ratio increased there was a linear decrease in the concentrations of isobutyric, isovaleric acid and the acetic: propionic acid ratio in digesta, 
which corroborates with the reductions in odour emissions reported by Garry et al. (2007) and Leek et al. (2007). By limiting protein fermentation and increasing carbohydrate fermentation in the large intestine, the production of some of the most offensive smelling compounds emanating from pig production can be reduced (Mackie et al., 1998). Both protein and carbohydrate fermentation contribute to the production of acetic acid; however, the BCFAs i.e. isobutyric and isovaleric acid are produced exclusively from protein fermentation and have a more offensive odour than the straight-chain VFAs (Mackie et al., 1998). Leek et al. (2007) found that there was a linear relationship between odour emission rate and the acetic: propionic acid ratio in the slurry, while Garry et al. (2007) reported that barleybased diets reduced odour by $47 \%$ compared with wheatbased diets when fed to grower finisher pigs. The linear decrease in BCFAs and acetic:propionic acid ratio in the colon would suggest that in the current study $666 \mathrm{~g} / \mathrm{kg}$ barley or $25 \mathrm{~g} / \mathrm{kg} \beta$-glucan would emit the least odourous compounds from pig houses.

There was a linear increase in total VFA concentration and in the molar proportions of propionic acid and butyric acid with increasing levels of dietary barley in the colon. SCFAs are the principal luminal anions, thus an increase in SCFA production lowers digesta pH (Bach Knudsen et al., 1991). Digesta caecum and colon pH was significantly reduced due to increases in total VFA as a consequence of increasing dietary barley level. The luminal environment created by the fermentation of barley $\beta$-glucans, increased concentrations of SCFAs and a low digesta $\mathrm{pH}$ is conducive to the production of beneficial bacteria at the expense of acid-sensitive Enterobacteria spp. (0'Connell et al., 2005). The linear reduction in Enterobacteria spp. concentrations with increasing dietary barley is probably due to the significant reduction in digesta pH. Mikkelsen et al. (2004) reported that a low $\mathrm{pH}$, as a result of high levels of lactic acid, killed Salmonella and Escherichia coli bacteria in the gastro-intestinal tract. Although many species of $E$. coli are commensal, Smith and Halls (1968) found that barley hulls reduced the incidence of enterotoxigenic haemolytic $E$. coli, which are responsible for post-weaning colibacillosis. Some E. coli species are acid intolerant and are not able to compete at a low $\mathrm{pH}<5.5$ (Prescott et al., 2002). When the $\mathrm{pH}$ drops below 5.5 to 6 , E. coli synthesise an array of new proteins as part of their 'acidic tolerance response' in an effort to cope with the pH change (Prescott et al., 2002). The average caecal $\mathrm{pH}$ of pigs offered the $666 \mathrm{~g} / \mathrm{kg}$ barley diet was 5.3, which may have been sufficient to upset the $\mathrm{pH}$ homeostasis of the Enterobacteria. The reduction in Enterobacteria concentrations due to the inclusion of barley in the diet is reflected in a higher faecal DM content and production of butyric acid in the colon compared with the pure wheat-based diet, indicating an improved gut function with efficient absorption of colonic water. Butyrate is rapidly metabolised by colonocytes supplying $70 \%$ of respiratory fuel (Roediger, 1995), therefore it is critical for the maintenance and metabolic integrity of the colonic epithelial cells. Given that the salvage function of the colon for absorption of unabsorbed sodium and water from the small intestine depends on the metabolic integrity of the colonic epithelial cells (Roediger, 1994), it is not unreasonable to expect that barley-based diets would result in higher faecal DM partly due to increased butyrate production (Williams et al., 2001).

There was no linear or quadratic effect of dietary barley on ammonia emissions. However, the pure barley-based diet had numerically reduced ammonia emissions compared with the pure wheat-based diet. This coincides with a linear increase in faecal $\mathrm{N}$ excretion and a numerical decrease in the urine: faeces $\mathrm{N}$ ratio as the level of dietary barley $\beta$-glucan increased. The effect of this is a shift in $\mathrm{N}$ excretion from its more volatile state as urea in urine to bacterial $\mathrm{N}$ in faeces (Mroz et al., 2000), thus limiting the capacity for rapid ammonia volatilisation.

In conclusion, there was a linear decrease in diet digestibility as the level of barley in the diet increased. However, this reduction in digestibility did not affect $\mathrm{N}$ retention. There was a linear decrease in BCFAs, acetic: propionic acid ratio, caecal Enterobacteria spp. and colonic butyrate proportion as the level of barley increased. This would suggest that $50 \mathrm{~g} /$ day of barley $\beta$-glucans is necessary in order to reduce odourous compounds in pig houses and to improve gut health.

\section{References}

Association of Official Analytical Chemists 1995. Official methods of analysis, 16th edition, AOAC, Washington, DC, USA.

Aumaitre A, Peiniau J and Made F 1995. Digestive adaption after weaning and nutritional consequences in the piglet. Pig News and Information 16, $73 \mathrm{~N}-79 \mathrm{~N}$.

Bach Knudsen KE and Hansen I 1991. Gastrointestinal implications in pigs of wheat and oat fractions. 1. Digestibility and bulking properties of polysaccharides and other major constituents. The British Journal of Nutrition 65, 217-232.

Bach Knudsen KE, Jensen BB, Andersen JO and Hansen I 1991. Gastrointestinal implications in pigs of wheat and oat fractions. 2. Microbial activity in the gastrointestinal tract. The British Journal of Nutrition 65, 233-248.

Campbell GL and Bedford MR 1992. Enzyme applications for monogastric feeds: a review. Canadian Journal of Animal Science 72, 449-466.

Charalampopoulos D, Wang R, Pandiella SS and Webb C 2002. Application of cereals and cereal components in functional foods: a review. International Journal of Food Microbiology 79, 131-141.

Close WH 1994. Feeding new genotypes: establishing amino acid/energy requirements. In Principles of pig science (ed. DJA Cole, J Wiseman and MA Varley), pp. 123-140. Nottingham University Press, UK.

Conway EJ 1957. Microdiffusion analysis and volumetric error. Crosby Lockwood and Son, London.

De Lange CFM 2000. Characterisation of the nonstarch polysaccharides. In Feed evaluation - principles and practice (ed. PJ Moughan, MWA Verstegen and MI Visser-Reyneveld), pp. 77-92. Wageningen Press, Wageningen, The Netherlands.

Derikx PJL and Aarnink AJA 1993. Reduction of ammonia emission from manure by application of liquid top layers. In Nitrogen flow in pig production and environmental consequences (ed. MWA Verstegen, LA Den Hartog, GJM Van Kempen and JHM Metz), EAAP publication no. 69, pp. 344-349. Purdoc, Wageningen, The Netherlands.

Garry BP, Fogarty M, Curran TP and O'Doherty JV 2007. The effect of cereal type and exogenous enzyme supplementation in pig diets on performance, odour and ammonia emissions from finisher pigs. Animal 1, 755-761. 
Gibson GR and Roberfroid MB 1995. Dietary modulation of the human colonic microbiota: introducing the concept of prebiotics. The Journal of Nutrition 125, 1401-1412.

Högberg A 2003. Cereal nonstarch polysaccharides in pig diets - influence on digestion site, gut environment and microbial populations. PhD thesis, Swedish University of Agricultural Sciences, Uppsala.

Högberg A and Lindberg JE 2004. Influence of cereal nonstarch polysaccharides and enzyme supplementation on digestion site and gut environment in weaned piglets. Animal Feed Science and Technology 116, 113-128.

Johnson IT and Gee JM 1981. Effect of gel-forming gums on the intestinal unstirred layer and sugar transport in vitro. Gut 22, 398-403.

Leek AGB, Hayes E, Curran TP, Callan JJ, Dodd VA, Beattie VE and O'Doherty JV 2007. The influence of manure composition on emissions of odour and ammonia from finishing pigs fed different concentrations of dietary crude protein. Bioresource Technology. Available online.

Littell RC, Milliken GA, Stroup WW and Wolfinger RD 1996. SAS ${ }^{\circledR}$ systems for mixed models. SAS institute Inc., Cary, NC, USA.

Macfarlane S and Macfarlane GT 2003. Regulation of short-chain fatty acid production. The Proceedings of the Nutrition Society $62,67-72$.

Mackie RI 1995. Microbial production of odour components. Proceedings of international round table on swine odour control, pp. 18-19. lowa State University, Ames.

Mackie RI, Stroot PG and Varel VH 1998. Biological identification and biological origin of key odour compounds in livestock waste. Journal of Animal Science 76, 1331-1342.

McCleary BV and Glennie-Holmes M 1985. Enzymatic quantification of $(1,3)(1,4)-\beta$-D-glucan in barley and malt. Journal of the Institute of Brewing 91, 285-295.

Mikkelsen LL, Naughton PJ, Hedemann MS and Jensen BB 2004. Effects of physical properties of feed on microbial ecology and survival of Salmonella enterica serovar typhimurium in the pig gastrointestinal tract. Applied and Environmental Microbiology 70, 3485-3492.

Mroz Z, Moeser AJ, Vreman K, van Diepen JTM, Van Kempen T, Canh TT and Jongbloed AW 2000. Effects of dietary carbohydrates and buffering capacity on nutrient digestibility and manure characteristics in finishing pigs. Journal of Animal Science 78, 3096-3106.

Nielsen EK and Ingvartsen KL 2000. Effect of cereal type, disintegration method and pelleting on stomach content, weight and ulcers and performance in growing pigs. Livestock Production Science 66, 271-282.
O'Connell M, Callan JJ, Byrne C, Sweeney T and O'Doherty JV 2005. The effect of cereal type and exogenous enzyme supplementation in pig diets on nutrient digestibility, intestinal microflora, volatile fatty acid concentration and manure ammonia emissions from pigs. Animal Science 81, 357-364.

O'Connell JM, Callan JJ and O'Doherty JV 2006. The effect of dietary crude protein level, cereal type and exogenous enzyme supplementation on nutrient digestibility, nitrogen excretion, faecal volatile fatty acid concentration and ammonia emission from pigs. Animal Feed Science and Technology 127, 73-88.

Porter MG and Murray RS 2001. The volatility of components of grass silage on oven drying and the inter-relationship between dry-matter content estimated by different analytical methods. Grass and Forage Science 56, 405-411.

Prescott LM, Harley JP and Klein DA 2002. Microbial growth. In Microbiology (ed. D Allen), pp. 112-135. McGraw Hill Co., OH.

Roberfroid M 1993. Dietary fiber, inulin and oligofructose: a review comparing their physiological effects. Critical Reviews in Food Science and Nutrition 33, 103-148.

Roediger WEW 1994. Famine, fibre, fatty acids and failed colonic absorption: does fibre fermentation ameliorate diarrhoea? Journal of Parenteral and Enteral Nutrition 18, 4-8.

Roediger WEW 1995. The place of short-chain fatty acids in colonocyte metabolism in health and ulcerative colitis: the impaired colonocyte barrier In Physiology and clinical aspects of short-chain fatty acids (ed. JH Cummings, JL Rombeau and T Sakata), p. 337. Cambridge University Press, UK.

Sauvant D, Perez JM and Tran G 2004. Tables of composition and nutritional value of feed materials. Pigs, poultry, cattle, sheep, goats, rabbits, horses, fish. Wageningen Academic Publishers, The Netherlands.

Smith HW and Halls S 1968. The production of oedema disease and diarrhoea in weaned pigs by the oral adminsatration of Escherichia coli: factors that influence the course of experimental disease. Journal of Medical Microbiology 1, 45-59.

Statistical Analysis Systems Institute 1985. Statistical analysis systems, version 6.12. SAS Institute Inc., Cary, NC.

Van Soest PJ, Robertson JB and Lewis BA 1991. Methods for dietary fibre neutral detergent fiber and non starch polysaccharides in relation to animal nutrition. Journal of Dairy Science 74, 3583-3597.

Williams BA, Verstegen MWA and Tamminga S 2001. Fermentation in the large intestine of single stomached animals and its relationship to human health. Nutrition Research Reviews 14, 207-227. 